\title{
Berbingkai Kemajemukan Budaya, Bersukma Desakalapatra: Selidik Etnografi atas Tradisi Tengger
}

\author{
The Embrace of Multiculturalism, Desakalapatra Energy: An Etnographic Study of \\ Tengger Tradition
}

\author{
Holifatul Hasanah ${ }^{1, *}$ dan Sony Sukmawan ${ }^{2}$ \\ ${ }^{1,2}$ Program Studi Pendidikan Bahasa dan Sastra Indonesia \\ FIB Universitas Brawijaya

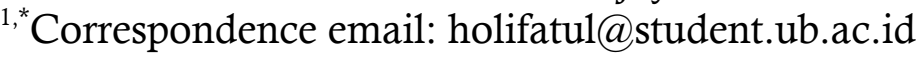 \\ ${ }^{2}$ Email: sony_sukmawan@ub.ac.id
}

Received: 26 Juli 2020 Revised: 20 Januari 2021 Accepted: 21 Januari 2021

\begin{abstract}
This research aims to reveal the representation of multiculturalism about the complexity of the Tengger tradition. This study used a qualitative approach to the design of ethnography. The data of this research are in the form of folkloristic expressions manifested in utterances or symbolic behavior. Sources of data in this study were native speakers of Tengger. Data were collected using observation and interviews. The data obtained were then analyzed through three stages: data reduction, data presentation, and conclusions. The research findings show that multiculturalism can be represented in various Tengger tradition. Some of them are present in karo celebration performance that contains traditions of gantenan cecelukan, andon mangan, and nyandaran. Instead of these traditions, the tolerance value is also indicated in sayan tradition, such as sayan hajatan, sayan of farming, sayan of building a house, and sayan of building a place of worship. The multicultural Tengger community recognizes the concept of desakalapatra, a different custom in every Tengger region. However, by the existence of traditional support, these differences were able to be managed well. The Tengger people became more open-minded in understanding and accepting any differences between them through multiculturalism and tolerance of desakalapatra value. The solid religious tolerance in the Tengger tradition is also affected in bonding the harmony. As a result, Tengger people are always unity both culture and tradition, though they believe diversity subsistence around them.
\end{abstract}

Keywords: multiculturalism, desakalapatra, tolerance, tradition, Tengger

Abstrak: Penelitian ini bertujuan mengungkap representasi multikulturalisme dalam kompleksitas tradisi Tengger. Penelitian ini menggunakan pendekatan kualitatif dengan desain etnografi. Data penelitian ini berupa ekspresi folkloristik yang memuat nilai dan gagasan praksis kemajemukan budaya yang terwujud dalam tuturan, atau perilaku simbolik. Data penelitian diperoleh dari sumber data, yaitu masyarakat Tengger, khususnya penutur langsung, dukun pandita, dan staf dukun pandita. Pengumpulan data dilakukan dengan menggunakan teknik observasi dan wawancara. Data yang diperoleh kemudian dianalisis melalui tiga tahapan, yaitu pereduksian data, penyajian data, dan penyusunan kesimpulan. Temuan penelitian menunjukkan bahwa multikulturalisme mampu direpresentasikan dalam berbagai tradisi yang ada di Tengger, beberapa diantaranya hadir dalam pelaksanaan perayaan karo yang di dalamnya terdapat tradisi gentenan cecelukan, andon mangan, dan nyandran. Selain itu, nilai toleransi juga tercermin dalam tradisi sayan, seperti: sayan hajatan, sayan bercocok tanam, sayan membangun rumah, dan sayan membangun tempat beribadah. Masyarakat Tengger yang multikultural mengenal adanya konsep desakalapatra yaitu kebiasan yang berbeda pada masing-masing wilayah Tengger. Perbedaan ini mampu dikelola dengan baik karena adanya sokongan tradisi. Nilai multikulturalisme dan toleransi dalam desakalapatra mengajarkan masyarakat Tengger untuk lebih terbuka dalam memahami dan menerima segala jenis perbedaan yang terjadi di sekitarnya. Toleransi beragama yang begitu kuat dalam tradisi Tengger turut berperan serta dalam merajut kerukunan. Oleh karena itu, meskipun orang Tengger memiliki keyakinan yang berbeda, mereka satu dalam budaya dan bersama dalam tradisi.

Kata Kunci : Multikulturalisme, desakalapatra, toleransi, tradisi, Tengger.

To cite this article:

Hasanah, H., \& Sukmawan, S. (2021). Berbingkai Kemajemukan Budaya, Bersukma Desakalapatra: Selidik Etnografi atas Tradisi Tengger. Diglosia: Jurnal Kajian Bahasa, Sastra, dan Pengajarannya, 4(1), 79-90.

https://doi.org/10.30872/diglosia.v4i1.102 


\section{A. PENDAHULUAN}

Adanya keberagaman dapat menjadi suatu tantangan dan ancaman. Tantangan keberagaman salah satunya adalah sikap toleran terhadap segala perbedaan di setiap sisi kehidupan. Selain itu, keberagaman juga dapat memicu rasa tidak dihargai, iri hati, kebencian, dan percekcokan, yang berujung pada perpecahan. Tanpa adanya pemahaman multikultural, keberagaman dapat menyebabkan adanya sikap intoleran, dan berakibat pada permasalahan sosial.

Gambaran peliknya konflik keberagaman yang terjadi di Indonesia selama 14 tahun terakhir ditunjukkan dalam ribuan kasus konflik. Konflik keragaman mencapai angka 2.398 kasus dengan rincian 65\% dilatarbelakangi agama, dan 20\% dilatarbelakangi etnik, sisanya dipicu oleh gender, dan kekerasan seksual (Kompas.com, 2020). Terjadinya berbagai konflik tersebut disebabkan oleh kurangnya sikap toleransi terhadap keberagaman. Di tengah maraknya konflik yang dipicu oleh keberagaman di Indonesia, terdapat masyarakat yang hidup rukun dan damai dengan kemajemukan budaya, yaitu wong Tengger. Mereka hidup membaur menjadi satu secara berdampingan dengan segala keberagaman tradisi dan agama yang dianut masyarakatnya. Berdasarkan latar belakang tersebut, maka peneliti tertarik untuk membahas mengenai multikulturalisme dalam tradisi Tengger, serta peran tradisi tersebut dalam merajut kerukunan Masyarakat Tengger.

Wong Tengger adalah sebutan bagi penduduk asli yang berdomisili di desa-desa Tengger. Desa Tengger merupakan wilayah di kabupaten Malang, Lumajang, Pasuruan, dan Probolinggo (Sutarto, 2008). Masyarakat Tengger adalah masyarakat yang multikultural. Banyak ahli berpendapat bahwa multikultural pada dasarnya merupakan konsep harmoni dalam keberagaman yang tumbuh seiring dengan kesederajatan di antara kebudayan yang berbeda-beda (Lestari, 2015, hal. 31). Sejalan dengan itu, menurut Yaqin (2005, hal. 9) multikultural dapat diartikan sebagai keberagaman budaya. Aspek keberagaman menjadi inti dari multikultural, yang kemudian berkembang menjadi sebuah ideologi yaitu multikulturalisme. Multikulturalisme juga dapat diartikan sebagai gerakan yang bukan hanya menuntut adanya pengakuan terhadap keberagaman dan perbedaaan, melainkan juga bagaimana keberagaman dan perbedaan tersebut bisa diperlakukan sama. Selain itu, Irhandayaningsih (2012, hal.9) mengatakan bahwa lahirnya multikulturalisme dilatarbelakangi oleh kebutuhan akan pengakuan terhadap keberagaman.

Masyarakat Tengger yang multikultural mampu hidup rukun dengan keberagaman yang ditopang dengan kekayaan tradisi. Beragam tradisi upacara Tengger dapat dikelompokan berdasarkan waktu pelaksanaannya. Upacara tersebut dibagi menjadi upacara bulanan, tahunan, serta lima tahunan. Dalam setahun, masyarakat Tengger melakukan beberapa rangkaian upacara, seperti: barikan setiap sebulan sekali, dan pujan setiap empat bulan sekali. Selain itu, terdapat ritual tahunan, seperti kasada, dan karo. Ada pula yang dilakukan lima tahun sekali, yakni upacara unan-unan. Bahkan upacara-upacara yang dilakukan individu juga banyak digelar, seperti: upacara kelahiran, tugel kuncung, walagara, entas-entas, dan lain sebagainya (Sukmawan et al., 2020, hal. 110). Tradisi-tradisi tersebut mereka lakukan bersama sebagai adat istiadat yang ada di suku Tengger untuk menjalin kerukunan (Haryanto, 2014).

Bagi masyarakat Tengger, keberagaman tradisi dijadikan sebagai ruang untuk membina sikap saling membantu dan menghormati. Sehingga menciptakan suatu 
keharmonisan dalam segala perbedaan. Hal ini diperkuat dengan pendapat Huda \& Khasanah (2019a, hal. 152) yang mengemukakan bahwa masyarakat Tengger memiliki sikap saling menghormati antar sesama. Selain itu, masyarakat Tengger juga menjunjung tinggi nilai persamaan serta demokrasi dalam kehidupan bermasyarakat. Karena wong Tengger menganggap bahwa mereka semua adalah saudara, dan keluarga yang harus rukun sesuai amanat para leluhur.

Masyarakat Tengger juga mengenal adanya konsep desakalapatra, yaitu tradisi dan kebiasan yang berbeda di masing-masing wilayah. Keberagaman ini juga mampu dikelola dengan baik oleh wong Tengger dengan menerapkan sikap toleransi. Dalam hal ini, toleransi dapat diartikan sebagai suatu perilaku atau sikap menghargai dan menghormati perilaku orang lain. Istilah toleransi dalam konteks sosial budaya dan agama berarti sikap yang melarang adanya diskriminasi terhadap golongan atau kelompok yang berbeda dalam suatu masyarakat (Bakar, 2015, hal. 123). Sejalan dengan itu, Casram (2016, hal. 191) memaknai toleransi sebagai sikap untuk membiarkan kebebasan kepada orang lain, dan memberikan kebenaran atas segala perbedaan sebagai bentuk pengakuan akan hak asasi manusia. Sikap toleransi ini mampu dicerminkan oleh masyarakat Tegger. Wong Tengger juga memiliki kehidupan yang cenderung mengedepankan rasa kekeluargaan, serta kerja sama kolektif dalam berbagai hal (Haryanto, 2014, hal. 203). Keberagaman tidak lantas menjadi jurang pemisah antar masyarakat Tengger, tetapi dijadikan sebagai suatu jembatan yang dapat dilalui dengan adaptasi dan toleransi. Oleh karena itu, hal ini menarik untuk diteliti.

Penelitian sebelumnya mengenai keberagaman dan kerukunan masyarakat Tengger pernah dilakukan oleh beberapa peneliti. Penelitian sejenis pernah dilakukan oleh Muhadi (2019) dengan judul penelitian Nilai-Nilai Pendidikan Agama Islam Multikultural dalam Masyarakat Muslim Tengger. Dalam penelitiannya, Muhadi membahas mengenai kehidupan muslim Tengger yang mampu menerima pendidikan agama Islam multikultural dengan adat tradisi Tengger, serta mampu mempertahankan nilai-nilainya.

Selain itu, penelitian lainnya juga pernah dilakukan oleh Huda \& Khasanah (2019b) yang berjudul The Relationship between Religious Tribes in Tengger (Hindu, Islam, and Budha). Hasil penelitian menunjukkan bahwa masyarakat suku Tengger merupakan komunitas adat yang kuat. Di tengah proses peradaban yang begitu lama, masyarakat Tengger selalu berpegang teguh pada peninggalan leluhur yang yang diwariskan secara turun-temurun. Meskipun masyarakat Tengger menganut agama yang berbeda-beda tidak sedikitpun menggoyahkan rasa kekeluargaan mereka. Keragaman ini justru semakin memperkuat kerukunan antar umat beragama yang berpegang teguh pada adat istiadat dan budaya. Kondisi kerukunan ini terwujud dalam praktek sosial masyarakat tengger, hubungan antar masyarakat juga terjalin baik karena sikap toleransi dalam masyarakat yang dilandasi nilai-nilai budaya tengger (Huda \& Khasanah, 2019b, hal. 295).

Penelitian-penelitian tersebut, lebih berfokus pada kerukunan dalam keberagaman agama masyarakat Tengger dan belum mampu mengungkap nilai multikulturalisme yang ada dalam tradisi-tradisi Tengger secara mendalam. Oleh karena itu, dalam penelitian ini akan diuraikan mengenai: Bagaimana multikulturalisme dalam tradisi Tengger? Bagaimana konsep desakalapatra dalam tradisi Tengger? Bagaimana peran tradisi sayan dalam merajut kerukunan masyarakat Tengger. Tujuan dilakukannya penelitian ini, yaitu untuk mengetahui 
multikulturalisme dalam tradisi Tengger, konsep desakalapatra dalam tradisi Tengger, serta peran tradisi-tradisi tersebut dalam merajut kerukunan masyarakat Tengger. Sehingga dapat diteladani dan diambil manfaatnya oleh masyarakat. Kajian ini tentunya relevan dengan banyaknya konflik mengenai keberagaman yang sering terjadi dalam beberapa tahun terakhir. Inilah salah satu alasan pentingnya penelitian ini dilakukan. Teori-teori yang berkaitan dengan multikulturalisme, dan toleransi keberagaman akan dijadikan dasar sekaligus pembanding dalam upaya menjelaskan fenomena-fenomena yang ditemukan.

\section{B. METODE}

Penelitian yang menggunakan Desa Tengger wilayah Kecamatan Tosari, Kabupaten Pasuruan sebagai lokus penelitian ini menggunakan pendekatan kualitatif dengan desain etnografi. Model ini digunakan untuk mengkaji peristiwa kultural yang menyajikan pandangan hidup subjek sebagai objek studi. Data penelitian ini berupa ekspresi folkloristik yang memuat nilai dan gagasan praksis kemajemukan budaya yang terwujud dalam ungkapan, tuturan, ekspresi lisan (oral), maupun tindak/gerak atau perilaku simbolik. Data penelitian diperoleh dari masyarakat Tengger, khususya pelaku/penutur langsung, dukun pandita, dan staf dukun pandita. Teknik wawancara digunakan untuk merekam data tradisi (lisan) masyarakat Tengger yang tidak dapat direkam melalui pengamatan (Sudikan, 2001, hal 87). Teknik observasi nonpartisipasi digunakan untuk pengumpulan data dengan cara mengamati aktivitas budaya, khususnya aktualisasi desakalapatra dalam tradisi Tengger. Analisis data etnografis penelitian ini dimulai dengan memilih situasi sosial (place, actor, activity), melaksanakan observasi, mencatat hasil observasi dan wawancara, mengajukan pertanyaan deskriptif, analisis wawancara etnografis, analisis ranah, mengajukan pertanyaan struktural, analisis taksonomi, mengajukan pertanyaan kontras, analisis komponensial, analisis tema kultural, dan menulis etnografi (Spradley, 2007).

\section{PEMBAHASAN}

\section{Multikulturalisme dalam Tradisi Tengger}

Tengger merupakan pusaka saujana (cultural landscape), jika dikelola dan dibina dengan baik memiliki eksistensi yang tidak hanya memberikan sumbangan berarti bagi dirinya sendiri, melainkan juga untuk Indonesia (Sutarto, 2006, hal. 1). Masyarakat Tengger merupakan masyarakat multikultural. Banyak ahli yang berpendapat bahwa multikultural pada dasarnya merupakan konsep harmoni dalam keberagaman yang tumbuh seiring dengan kesederajatan di antara kebudayan yang berbeda-beda (Lestari, 2015, hal. 31). Sejalan degan itu, Yaqin (2005) mengemukakan bahwa aspek keberagaman menjadi inti dari multikultural, yang kemudian berkembang menjadi sebuah ideologi yaitu multikulturalisme. Multikulturalisme secara sederhana dapat dimaknai sebagai pengakuan bahwa sebuah masyarakat adalah majemuk dan beragam (Baidhawy, 2005, hal. 7). 
Kita orang Tengger menyadari bahwa unsur perbedaan itu adalah demi kemakmuran. Karena Tuhan tidak menciptakan manusia itu sama, melainkan berbeda-beda. Untuk itu, orang Tengger sangat menghargai perbedaanperbedaan itu (Wawancara Pak Kariadi pada 19 Juni 2020).

Pada situasi masyarakat yang multikultural seperti di Tengger, potensi disosiatif cenderung menjadi lebih kuat dari asosiatif. Namun, hal itu tidak terjadi, karena orang Tengger mampu menjaga ikatan dalam segala perbedaan. Lebih lanjut Haryanto (2014, hal. 204) mengemukakan bahwa pengalaman panjang yang dilakukan masyarakat untuk mengelola keberagaman agar tetap terjalin sebuah kerukunan berwujud dalam bentuk tradisi yang menguatkan kohesi sosial antar masyarakat.

Orang Tengger sangat kental dengan multikultural. Di sini terdapat banyak perbedaan, seperti: perbedaan agama, perbedaan dalam hal tata cara dan kebiasaan. Selain itu, sekarang tidak hanya orang Tengger saja, banyak pendatang, tetapi semuanya saling menghargai, damai, dan harmonis dan melaksanakan tradisi yang ada. Jadi, orang Tengger itu tetap saling membantu dalam menjalankan tradisi, baik dalam perayaan upacara, selametan atau hajatan, mapun perayaan hari raya. Bukan hanya itu, dalam acara keagamaan pun juga saling membantu. Karena adanya tradisi ini kami sering berkumpul tanpa mempermasalahkan perbedaan (Wawancara Romo Keto pada 19 Juni 2020).

Masyarakat Tengger yang multikultural mampu hidup rukun dengan keberagaman yang ditopang kekayaan tradisi. Bagi mereka, tradisi merupakan ruang untuk membina sikap saling menghormati dan membantu antar sesama. Sehingga tercipta keharmonisan dalam segala perbedaan. Perbedan-perbedaan ini mendorong upaya terwujudnya pluralisme (Suparlan, 2002, hal. 10). Semangat pluralisme orang Tengger yang diejahwantahkan melalui sikap budaya, tradisi, dan agama membuat masyarakat Tengger mampu terbebas dari konflik yang berkaitan dengan keberagaman.

Beragam tradisi yang ada di Tengger diikuti oleh semua warga Tengger tanpa membeda-bedakan kelas sosial, agama, dan sebagainya. Hal ini dikarenakan tradisi merupakan suatu budaya yang harus dipelihara dan turut menjadi penguat antar sesama warga Tengger. Tradisi-tradisi tersebut dijadikan sebagai sarana pertemuan antar warga sehingga mampu merekatkan kerukunan dalam keberagaman.

Salah satu bentuk tradisi yang di dalamnya terdapat nilai multikulturalisme yang begitu kuat adalah upacara Karo. Upacara Karo atau hari raya bagi orang Tengger ini merupakan upacara rutinitas yang dilakukan setiap tahun. Perayaan ini disambut dengan suka cita oleh seluruh warga Tengger tanpa terkecuali. Pada perayaan hari raya Karo orang Tengger saling mengunjungi rumah tetangga maupun saudara untuk memberikan ucapan selamat Karo dan saling bermaafan satu sama lain.

Upacara Karo dilakukan oleh semua warga Tengger. Orang yang sudah berdiam di Tengger maka akan otomatis melakukan semua upacara yang ada di Tengger. Orang Tengger memiliki penganut agama yang beragam, yaitu Hindu, Muslim, Kristen, Budha. Tapi untuk pelaksanaan adat semuanya diikuti oleh warga yang 
berbeda-beda agama itu. Jadi tidak ada yang membeda-bedakan. Kita juga saling menghormati, misalnya dalam upacara Karo, mereka yang beragama selain Islam tidak memasak apa yang tidak boleh dimakan oleh orang muslim (Wawancara Pak Kariadi pada 2 Juni 2020).

Upacara Karo merupakan upacara yang dilakukan seluruh lapisan masyarakat Tengger dari berbagai kalangan tanpa memandang agama, usia, maupun profesi. Mereka berbaur menyatu dalam suka cita perayaan upacara Karo. Istilah Karo berasal dari bahasa Tengger Karo yang memiliki arti 'dua'. Orang Tengger memiliki kalender sendiri, yaitu Kasa, Karo, Katiga, Kapat, Kalima, Kanem, Kapitu, Kawolu, Kasanga, Kasepuluh, Kadesta, dan Kasada. Upacara tersebut dinamakan Karo karena dilaksanakan pada bulan Karo, yaitu bulan kedua menurut sistem kalender Tengger.

Upacara Karo dilakukan dalam beberapa rangkaian, yaitu: Ngumpul, Mepek, Tekane Ping Pitu, Prepegan, Sodoran, Sesanding, Nyandran, dan Mulihe Ping Pitu (Batoro, 2017, hal. 18). Perayaan tersebut dapat berlangsung selama satu sampai dua minggu tergantung pada keadaan dan jumlah penduduk desa yang melaksanakan upacara, hal ini disebut desakalapatra.

Upacara Karo diikuti oleh semua warga tidak terbatas pada agama, karena upacara Karo ini merupakan upacara tradisi dan upacara untuk para leluhur Tengger. Sehingga seluruh warga wajib melestarikan tanpa memandang agama yang berbeda-beda (Wawancara Romo Keto pada 2 Juni 2020).

Upacara Karo bertujuan untuk memberi penghormatan kepada leluhur. Leluhur bagi masyarakat Tengger terdiri atas leluhur pribadi dan leluhur besar. Jika ada orang yang meninggal dalam suatu keluarga akan disebut sebagai leluhur pribadi. Leluhur pribadi, seperti kakek, nenek, dan lain sebagainya. Berbeda halnya dengan leluhur besar, yaitu leluhur daerah. Leluhur daerah adalah leluhur yang menjadi cikal bakal daerah dan membuka daerah tersebut. Leluhur daerah Tengger adalah Roro Anteng dan Joko Seger.

Dalam pelaksanaan upacara Karo masyarakat saling membantu tanpa membeda-bedakan kelas, agama, dan dari mana mereka berasal. Salah satu bentuk penghargaan dari orang nonmuslim terhadap orang muslim adalah, mereka tidak memasak apa yang tidak boleh dimakan oleh orang muslim. Sutarto (2006, hal. 7) mengemukakan bahwa selama pelaksanaan upacara ini, puluhan ternak baik sapi, ayam, mapun kambing disembelih agar bisa dinikmati dagingnya oleh orang yang merayakan upacara ini. Namun, jika ada keluarga yang tidak mampu, pengadaan ternak dilakukan secara berpatungan oleh orang yang lebih mampu. Hal itu, dilakukan untuk membina sikap toleransi dan saling membantu antar sesama warga Tengger.

Pembukaan Karo (tari sodoran) dilaksanakan di suatu tempat secara bersamaan. Setelah pembukaan dilaksanakan maka upacara dilanjutkan di masing-masing rumah warga. Kemudian, dukun Tengger mendatangi rumah warga secara bergilir untuk mendoakan orang yang memiliki hajat meskipun memiliki agama berbedabeda.

Selain itu, masyarakat Tengger juga memiliki tradisi gentenan. Menurut Haryanto (2014, hal. 210) gentenan memiliki arti 'gantian' atau memberikan balas budi secara setimpal terhadap pihak yang memberikan kebaikan kepadanya. 
Bergantian saling memanggil untuk diajak makan bersama dinamakan gentenan cecelukan. Biasanya gentenan ini dilakukan melalui kesepakatan beberapa orang untuk saling bergantian mengundang makan kenalan atau tetangganya. Undangan makan ini tidak hanya terbatas pada kelompok sesama agama saja, melaikan untuk semua warga Tengger.

Dalam salah satu rangkaian upacara Karo, orang Tengger melakukan andon mangan yaitu datang bertamu dan makan-makan. Walaupun sedikit para tamu harus memakan masakan tuan rumah. Tujuannya agar mereka saling merasakan. Ibaratnya senang sama-sama dirasakan, susah sama-sama dirasakan. Pelaksanaan andon mangan merupakan salah satu cara orang Tengger untuk mempererat keberagaman yang ada di Tengger. Karena dalam andon mangan tidak mengenal dari agama apapun, semua saling mengunjungi dari rumah yang satu ke rumah yang lain (Wawancara Romo Keto pada 2 Juni 2020).

Salah satu rangkaian upacara Karo yang ditunggu-tunggu, yaitu andon mangan. andon mangan merupakan tradisi berkunjung ke rumah orang lain dan makan bersama. Sikap tolerasi dalam keberagaman juga sangat kuat dalam tradisi ini. Para warga Tengger tidak mempermasalahkan agama apapun yang dianut oleh tuan rumah. Dalam tradisi ini warga yang berkunjung harus memakan apa yang disajikan oleh tuan rumah, hal ini merupakan bentuk penghargaan atas pemberian yang telah diberikan. Untuk itu, jika tuan rumah beragama non muslim, mereka tidak menyuguhkan makanan yang tidak boleh dimakan oleh orang muslim. Hal itu, dilakukan sebagai wujud toleransi, sehingga warga yang datang bertamu dapat menikmati segala hidangan yang diberikan.

Dalam rangkaian upacara Karo juga terdapat pelaksanaan nyadran. Nyadran dilakukan dengan mendatangi makam-makam leluhur. Hampir semua warga bersama-sama megikuti nyandran, karena menurut masyarakat Tengger orang Muslim masih memiliki leluhur Hindu, begitupun agama lainnya. Makam leluhur keluarga mereka tidak dipisah antar agama, tetapi dijadikan satu di tempat.

Pengakuan orang Tengger terhadap kesamaan derajat dari segala keberagaman tampak dalam berbagai tradisi yang ada di Tengger, salah satunya dalam rangkaian upacara Karo. Sikap saling menghargai, menghormati, toleran dalam keberagaman, serta tolong-menolong dalam pelaksanaan ragkaian upacara Karo mampu mencerminkan adanya nilai multikulturalisme. Sikap orang Tengger dalam pelaksanaan upacara Karo mengisyaratkan adanya kemauan yang kuat dalam mengakui segala perbedaan serta memelihara kesatuan masyarakat, atas dasar memelihara keberagaman bukan dengan mengingkari atau menghapuskan keberagaman yang ada. Hal ini sejalan dengan pendapat Nurcahyono\&Astutik (2018, hal. 6) bahwa masyarakat Tengger hidup dalam keberagaman namun mampu bersatu dengan keberagaman yang ada. Perbedaan seyogyanya tidak dapat menjadikan masyarakat Tengger rentan terhadap intoleransi dan konflik, namun justru sebaliknya mereka disatukan dengan segala tradisi yang dilestarikan secara turun-temurun. 


\section{Desakalapatra dalam Tradisi Tengger}

Masyarakat Tengger yang multikultural mengenal adanya konsep desakalapatra yaitu kebiasan yang berbeda pada masing-masing wilayah Tengger. Perbedaan ini mampu dikelola dengan baik karena adanya sokongan tradisi. Sudah diketahui umum bahwa masyarakat Tengger memiliki beraneka ragam tradisi. Salah satu tradisi yang sampai saat ini hidup, yaitu pelaksanaan upacara secara periodik. Upacara Tengger digolongkan menjadi dua, yaitu upacara komunal dan upacara personal. Upacara komunal dibagi lagi menjadi (1) upacara bulanan, contohnya barikan, (2) upacara empat bulanan, misalnya pujan, (3) upacara satu tahunan, salah duanya adalah kasada dan Karo, serta (4) upacara lima tahunan, yakni unan-unan. Selain itu, terdapat upacara yang dilakukan secara personal, antara lain mitoni, among-among, leliwet, walagara, entas-entas, tugel kuncung, dan lain sebagainya. Dalam pelaksanaan tradisi upacara-upacara tersebut terdapat sedikit perbedaan yang mengikuti kebiasan dimana mereka tinggal.

Dalam pelaksanaan tradisi, salah satunya upacara Karo dilaksanakan dengan jumlah hari yang berbeda-beda tergantung desanya. Perbedaan jumlah dan waktu itu bisa dianggap desakalapatra. Dalam hal ini desa berarti 'tempat', kala memiliki arti 'waktu', dan patra memiliki arti 'keadaan'. Desakalapatra merupakan keadaan yang menyesuaikan tempat dan waktu. Terkait dengan waktu pelaksanaan upacara Karo ini tergantung jumlah masyarakatnya, dan keadaan desanya (Wawancara Romo Keto pada 2 Juni 2020).

Mengenai konsep desakalapatra, Desa adalah tempat, kala adalah waktu, patra adalah keadaan. Jadi orang Tengger itu bisa saja mengikuti kebiasaan dimana mereka tinggal. Setiap desa memiliki kebiasaan yang tidak sama. Misalnya dalam upacara Karo atau tradisi lainnya di setiap wilayah hampir sama tetapi ada sedikit yang membedakan, itu terkait dengan desakalapatra-nya (Wawancara Pak Kariadi pada 2 Juni 2020).

Desakalapatra dapat dimaknai sebagai penyesuaian tradisi berdasarkan keadaan, waktu, dan tempat tradisi itu dilaksanakan. Terkait dengan pelaksanaan upacara Karo bergantung pada keadaan desa dan jumlah masyarakat yang tinggal di desa tersebut. Dalam upacara Karo, jika desa yang menjadi tempat pelaksanaan upacara relatif besar dan memiliki jumlah warga yang banyak, maka pelaksanaan upacaranya cenderung lebih lama jika dibandingkan dengan di desa yang memiliki jumlah penduduk yang sedikit. Pelaksanaan upacara Karo di desa Tosari dilakukan selama enam hari, sementara itu di desa Ngadiwono dilakukan selama tujuh hari. Berbeda halnya dengan di Wonokitri yang dilaksanakan selama tiga hari, dan di Sedaeng selama empat hari. Perbedaan-perbedaan mengenai jumlah masyarakat dan waktu pelaksanaan upacara ini dianggap desakalapatra oleh orang Tengger.

Orang Tengger tidak pernah mempermasalahkan mengenai adanya sedikit perbedaan-perbedaan dalam tradisi yang dilakukan. Perbedaan ini tidak dijadikan sebagai suatu halangan, lebih-lebih karena pemangku adat Tengger sangat menghargai pilihan dan menghormati perbedaan. Sikap toleran sudah menjadi bagian dari kearifan lokal. 
Desakalapatra merupakan suatu konsep yang dijadikan sebagai acuan sosial dalam tradisi masyarakat Tengger. Konsep ini berperan sebagai pedoman dalam memperluas pemahaman masyarakat mengenai cara pandang yang berbeda terhadap sesuatu. Selain itu, desakalapatra mengajarkan masyarakat suku Tengger untuk lebih terbuka dalam memahami dan menerima segala jenis perbedaan yang terjadi di sekitarnya. Nilai multikulturalisme dan toleransi dalam desakalapatra menjadikan Tengger layaknya sebuah miniatur keberagaman. Hidup dalam beragam keyakinan dan kekayaan tradisi, namun mampu tinggal berdampingan secara harmonis dan rukun dengan toleransi.

\section{Peran Tradisi Sayan dalam Merajut Kerukunan}

Multikulturalisme menjadi isu yang sering diperbincangkan pasca terjadinya berbagai konflik yang berkaitan dengan SARA di Indonesia. Haris (2012, hal. 52) mengemukakan bahwa kebanyakan dari konflik yang terjadi dipicu oleh adanya tindakan-tindakan seseorang atau kelompok tertentu yang intoleran. Kemudian, dibawa ke dalam kelompok-kelompok yang lebih luas dengan mengatas-namakan agama, budaya, dan suku. Akibatnya muncul konflik besar yang membawa bencana bagi berbagai pihak, tidak terkecuali pihak yang tidak terlibat didalamnya. Hal ini dapat menggambarkan bahwa bukan perkara mudah mempersatukan segala keberagaman tanpa didukung oleh kesadaran masyarakat multikultural (Lestari, 2015, hal. 31).

Berbeda dengan peliknya konflik keberagaman yang terjadi di Indonesia, masyarakat Tengger mampu hidup harmonis dengan segala perbedaan. Hal ini dapat terwujud karena adanya sikap toleransi antar sesama yang begitu kuat. Orang Tengger sangat menyadari bahwa setiap masyarakat maupun perseorangan memiliki kebutuhan untuk diakui, yang menuntut terciptanya penghargaan secara sosial.

Contoh toleransi dalam keberagaman, orang Tengger kalau punya hajat itu tidak memandang agama apapun. semuanya datang membantu, para perempuan membantu di dapur, sedangkan yang laki-laki membantu apa yang wajib dikerjakan oleh orang laki-laki. Bukan hanya mau pelaksanaan hajatan saja, masih ada sebagian saling membantu dalam bercocok tanam dan membuat rumah, namanya sayan. Hal ini merupakan bentuk toleransi oleh masyarakat Tengger yang multikultural (Wawancara Romo Keto 2 Juni 2020).

Bentuk kerukunan dalam keberagaman orang Tengger salah satunya diwujudkan dengan sikap saling membantu dalam pelaksanaan tradisi sayan. Jika ada saudara maupun tetangga yang memiliki hajat, mereka saling membantu tanpa memandang status sosial dan agama apa yang dianut oleh orang yang memiliki hajat. Para wanita membantu di dapur, sedangkan para laki-laki juga saling membantu dalam mempersiapkan segala keperluan. Tidak hanya dalam pelaksanaan hajat, masyarakat Tengger yang mayoritas penduduknya berprofesi sebagai petani juga saling membantu dalam bercocok tanam. Selain itu, mereka juga saling membantu jika ada saudara atau tetangganya ingin membangun rumah. Pelaksanaan tradisi sayan hajatan, sayan bercocok tanam, dan sayan membangun rumah adalah potret kerukunan masyarakat Tengger. Kesediaan membantu dalam 
keseluruhan tradisi tersebut tanpa melihat latar belakang seseorang menunjukkan pengakuan terhadap perbedaan dan keberagaman.

Beberapa bentuk keharmonisan masyarakat Tengger adalah saling membantu dalam membuat tempat peribadatan seperti masjid, gereja, dan pura. Karena sikap toleransi dan sikap menjaga tradisi yang dianut, membuat masyarakat Tengger tidak diterpa oleh konflik dalam keberagaman (Wawancara Romo Sukarji pada 3 Juni 2020).

Menariknya, masyarakat Tengger memiliki kepedulian yang tinggi terhadap kepentingan agama yang justru tidak mereka peluk. Beragam agama yang mereka anut tidak lantas membuat mereka mengedepankan kepentingan agama masingmasing. Bahu-membahu dalam membangun tempat peribadatan, seperti dalam pembangunan masjid, musalah, pura, dan tempat peribadatan lainnya, dilakukan oleh semua masyarakat Tengger tanpa terkecuali. Sayan membangun tempat ibadah bukan sesuatu yang baru, apalagi tabu.

Orang Tengger tidak meributkan masalah agama apa dan dari golongan mana. Jadi, yang penting melakukan kehidupan secara normal, saling menghormati, berperilaku jujur, itu yang diinginkan oleh orang Tengger. Mereka tidak mempermasalahkan entah itu agamanya apa, dan bajunya apa. Karena adanya tradisi-tradisi yang ada di Tengger ini, konflik yang berkaitan dengan keberagaman itu tidak ada (Wawancara Romo Keto pada 2 Juni 2020).

Secara sederhana sikap toleransi dalam tradisi orang Tengger dapat dimaknai sebagai sikap untuk membiarkan kebebasan kepada orang lain, dan memberikan kebenaran atas segala perbedaan sebagai bentuk pengakuan akan hak asasi manusia. Menurut Casram (2016, hal. 191) toleransi beragama merupakan toleransi yang mencakup keyakinan dalam diri manusia yang berhubungan dengan akidah yang dia yakini. Terkait dengan sikap toleransi beragama, terdapat dua tipe toleransi, yaitu toleransi aktif dan toleransi pasif. Toleransi pasif merupakan sikap menerima segala perbedaan sebagai sesuatu yang bersifat faktual, sedangkan toleransi aktif merupakan sikap menerima dan melibatkan diri melakukan kerja sama dengan orang lain di tengah perbedaan. Kebanyakan masyarakat di Indonesia masih mengedepankan toleransi pasif, tetapi tidak dengan orang Tengger. Mereka tidak hanya mengakui dan menghargai keberagaman agama, tetapi juga turut berkerja sama dan saling tolong-menolong dalam kehidupan sosial yang direpresentasikan dalam pelaksanaan tradisi, hal ini merupakan bentuk toleransi aktif.

Agama mengajarkan bahwa kebaikan tidak hanya terbatas pada ritual ibadah antara penganut beragama dengan Tuhan, yang biasa disebut kesalehan personal. Melainkan juga antara sesama manusia dengan menunjukkan rasa peduli dengan tolong-menolong untuk kepentingan umum, yang merupakan bagian dari kesalehan sosial (Falah, 2016). Kesalehan sosial selalu bertumpu pada kesalehan personal atau keimanan yang kuat. Meskipun orang Tengger memiliki keyakinan yang berbeda, tetapi mereka satu dalam budaya, dan bersama dalam tradisi.

Kebebasan untuk menganut agama yang berbeda oleh masing-masing orang sudah seharusnya dihargai, karena agama adalah elemen fundamental yang ada dalam kehidupan manusia (Arifin, 2016, hal 8). Konsepsi toleransi dan kerukukan 
antar umat beragama merupakan dua bentuk yang tidak dapat dipisahkan satu dengan yang lain, terdapat hubungan kausalitas diantara keduanya. Oleh karena itu, adanya toleransi antar umat beragama dalam tradisi orang Tengger, berperan serta dalam merajut kerukunan antar masyarakat beragama. Sehingga diharapkan mampu mencegah adanya konflik mengenai keberagaman yang dipicu pemaknaan distingtif yang bertumpu pada relasi "mereka" dan "kami".

\section{PENUTUP}

Masyarakat Tengger merupakan masyarakat yang multikutural. Dibalik kerukunan orang Tengger terdapat keberagaman yang menjadi pilar penyangga keharmonisan Tengger. Multikulturalisme mampu direpresentasikan dalam tradisitradisi yang hidup di Tengger. Beberapa diantaranya hadir dalam pelaksanaan perayaan Karo yang di dalamnya terdapat tradisi gentenan cecelukan, andon mangan, dan nyandran. Selain itu, nilai toleransi yang begitu kuat juga hadir dalam tradisi sayan baik sayan hajatan, sayan bercocok tanam, sayan membangun rumah, maupun sayan membangun tempat beribadah, yang menjadi potret kerukunan masyarakat Tengger.

Orang Tengger mengenal adanya konsep desakalapatra, yaitu tradisi dan kebiasan yang berbeda di masing-masing wilayah. Nilai multikulturalisme dan toleransi dalam desakalapatra mengajarkan masyarakat Tengger untuk lebih terbuka dalam memahami dan menerima segala jenis perbedan. Perbedaan ini tidak lantas dijadikan sebagai suatu halangan, lebih-lebih karena pemangku adat Tengger sangat menghargai pilihan dan menghormati perbedaan.

Masyarakat Tengger tidak hanya mengakui dan menghargai keberagaman, tetapi juga turut berkerja sama dan saling tolong-menolong dalam kehidupan sosial yang direpresentasikan dalam pelaksanaan tradisi. Sikap toleransi beragama dalam berbagai tradisi yang ada di Tengger sangat berperan penting untuk merajut kerukunan dalam keberagaman. Oleh karena itu, meskipun orang Tengger memiliki keyakinan yang berbeda, tetapi mereka tetap satu dalam budaya, dan bersama dalam tradisi.

\section{DAFTAR PUSTAKA}

Arifin, B. (2016). Implikasi Prinsip Tasamuh (Toleransi) dalam Interaksi antar Umat Beragama. Fikri: Jurnal Kajian Agama, Sosial, dan Budaya, 1(2), 391-420. https://journal.iaimnumetrolampung.ac.id/index.php/jf/article/view/20

Baidhawy, Z. (2005). Pendidikan Agama Berwawasan Multikultural. Jakarta: Erlangga. Bakar, A. (2015). Konsep Toleransi dan Kebebasan Beragama. Toleransi Media Komunikasi Umat Beragama, 7(2), 123-131. http://dx.doi.org/10.24014/trs.v7i2.1426

Batoro, J. (2017). Keajaiban Bromo Tengger Semeru: Analisis Kehidupan Suku TenggerAntropologi-Biologi di Ligkungan Bromo Tengger Semeru Jawa Timur. Malang: UB Press.

Casram. (2016). Membangun Sikap Toleransi Beragama dalam Masyarakat Plural. Wawasan: Jumal Ilmiah Agama dan Sosial Budaya, 1(2), 187-198. https://journal.uinsgd.ac.id/index.php/jw/article/view/588/700

Falah, R. Z. (2016). Membentuk Kesalehan Individual dan Sosial Melalui Konseling 
Mutikultural. KONSELING RELIGI: Jurnal Bimbingan Konseling Islam, 7(1), 163188. http://dx.doi.org/10.21043/kr.v7i1.1666

Haris, H. (2012). Revitalisasi dan Reinterpretasi Pendidikan Pancasila: Upaya Mengatasi Fenomena Konflik Kekerasan Melalui Sektor Pendidikan. In Sapriya (Ed.), Transformasi Empat Pilar Kebangsaan dalam Mengatasi Fenomena Konflik dan Kekerasan: Peran Pendidikan Kewarganegaraan. Bandung: Kerjasama Program Studi PKn Pascasarjana Universitas Pendidikan Indonesia, Asosiasi Profesi PKn se-Indonesia, dan Lembaga Ketahanan Nasional.

Haryanto, J. T. (2014). Kearifan Lokal Pendukung Kerukunan Beragama pada Komunitas Tengger Malang Jatim. Analisa: Journal of Social Science and Religion, 21(2), 201-2013. https://doi.org/10.18784/analisa.v21i02.15

Huda, M.T. \& Khasanah, I. (2019a). Budaya sebagai Perekat Hubungan antara Umat Beragama di Suku Tengger. Sangkep: Jurnal Sosial Keagamaan, 2(2), 151170. https://doi.org/10.20414/sangkep.v2i2.801

Huda, M.T. \& Khasanah, I. (2019b). The Relationship between Religious Tribes in Tengger (Hindu, Islam, and Budha). Vidyottama Sanatana: International Journal of Hindu Science and Religious Studies, 3(2), 284-296. http://dx.doi.org/10.25078/ijhsrs.v3i2.748

Irhandayaningsih, A. (2012). Kajian Filosofis terhadap Multikulturalisme Indonesia. HUMANIKA, 15(9). https://doi.org/10.14710/humanika.15.9.

Kompas.com. (2020). Kasus Kekerasan yang Dipicu Masalah Keberagaman di Indonesia. https://www.kompas.com/skola/read/2020/02/06/190000569/kasus-

kekerasan-yang-dipicu-masalah-keberagaman-di-indonesia

Lestari, G. (2015). Bhineka Tunggal Ika: Khasanah Multikultural Indonesia di Tengah Kehidupan SARA. Jurnal Pendidikan Pancasila dan Kewarganegaraan, 28(1), 31-37. http://dx.doi.org/10.17977/jppkn.v28i1.5437

Muhadi, I. (2019). Nilai-Nilai Pendidikan Islam Multikutural dalam Mayarakat Muslim Tengger. Pendidikan Multikultural, 3(2), 151-160. http://dx.doi.org/10.33474/multikultural.v3i2.4756

Nurcahyono, O. H. \& Astutik, D. (2018). Harmonisasi Masyarakat Adat Suku Tengger (Analisis Keberadaan Modal Sosial pada Proses Harmonisasi pada Masayarakat Adat Suku Tengger, Desa Tosari, Pasuruan, Jawa Timur). Dialektika Masyarakat: Jurnal Sosiologi, 2(1), 1-12. https://jurnal.uns.ac.id/dmjs/article/view/23326/17016

Spradley, J. P. (2007). Metode Etnografi. Yogyakarta: Tiara Wacana Yogya.

Sudikan, S. Y. (2001). Metode Penelitian Kebudayaan. Surabaya: Citra Wacana.

Sukmawan, S., Ramadhani, A., \& Firdaus, E. (2020). Pesan Edukasi Seksual bagi Remaja Tengger Melalui Tari Sodoran. Gondang: Jurnal Seni dan Budaya, 4(2), 109-118. https://doi.org/10.24114/gondang.v4i2.19210

Suparlan, P. (2002). Multikulturalisme. Jurnal Ketahanan Nasional, 7(1), 9-18. https://doi.org/10.22146/jkn.22071

Sutarto, A. (2006). Sekilas tentang Masyarakat Tengger. http://kebudayaan.kemdikbud.go.id/bpnbyogyakarta/wpcontent/uploads/sites/24/2014/06/Masyarakat_Tengger.pdf

Sutarto, A. (2008). Kamus Budaya dan Religi Tengger. Jember: Lembaga Penelitian, Universitas Jember.

Yaqin, A. (2005). Pendidikan Multikultural. Yogyakarta: Pilar Media. 